\title{
Boron clusters: Do they receive the deserved interest?*
}

\author{
Francesc Teixidor ${ }^{\ddagger}$, Clara Viñas, Albert Demonceau, and \\ Rosario Nuñez \\ Institut de Ciència de Materials de Barcelona (CSIC), Campus U.A.B., E-08193 \\ Bellaterra, Spain
}

\begin{abstract}
New applications in which the carborane and metallacarborane species play a crucial role have been recently developed. In these applications, clusters display many particular characteristics that do not find parallel in their organic counterparts. The $o$-carborane can modulate the $\mathrm{C} \cdots \mathrm{C}$ distances depending on the substituents bonded to the cluster carbon atom and can lead to the formation of uncommon halogenophosphane charge-transfer "spoke" complexes with iodine due to their electron-withdrawing capacity. Besides, metallacarboranes have been used as doping agents in organic conducting polymers and as catalysts in Kharasch reactions.
\end{abstract}

\section{INTRODUCTION}

Boron clusters, boranes and carboranes, display many particular characteristics that do not find parallel in their organic counterparts. On the other hand, the chemistry of carboranes seems to be very much related to organic chemistry. This is why in attempting new reactions chemists working with boron clusters get inspired in operative organic. The opposite is, however, seldom true. The view of boranes or carboranes as rare, strange, or esoteric, in addition to having a high price and an assumed, unrealistically low stability precludes synthetic chemists in other areas to think of these clusters as real building blocks. The advent of materials science with emphasis in new tridimensional structures should correct this vision. In this paper, we report briefly on some recent new applications developed in our group in which the carborane or metallacarborane species play a crucial role. We will not report on applications such as BNCT [1], weakly coordinating anions for catalysis [2], other sorts of homogeneous catalysis [3], or the well-known radionuclides extraction [4,5], as they are very well acknowledged, and extensive reviews already exist.

\section{METALLACARBORANE ANIONS AS DOPING AGENTS IN CONDUCTING ORGANIC POLYMERS}

One of the potential applications of organic conducting polymers (COPs) is to use them as substitutes for metals or inorganic semiconductors [6]. However, a major obstacle to their commercialization is the relatively poor stability of the conducting polymer-based devices [7] which present several degradation mechanisms. One is associated with rapid oxidation by water or oxygen [8-10]. The conducting phase can be made insulating by applying a reducing potential. Therefore, conducting and reducing states can be electrochemically generated. The conducting state is the one requiring the doping anions, and is pro-

\footnotetext{
${ }^{*}$ Lecture presented at the $\mathrm{XI}^{\text {th }}$ International Meeting on Boron Chemistry (IMEBORON XI), Moscow, Russia, 28 July-2 August 2002. Other presentations are published in this issue, pp. 1157-1355.

${ }^{\ddagger}$ Corresponding author: E-mail: teixidor@icmab.es
} 
duced by oxidizing the insulating material. Common doping agents responsible for the switch between the insulator and conducting phases, e.g., $\mathrm{Cl}^{-},\left[\mathrm{NO}_{3}\right]^{-}$, dodecylbenzene sulfonate (DBS), dodecyl sulfonate, naphthalene sulfonate [11-13], are coordinating anions, therefore nucleophiles. One of their main characteristics is the minor delocalization of the anionic charge throughout its volume. Considering that nucleophilicity is a problem, anions with high charge delocalization could improve the overoxidation resistance of the COPs [14]. We recently [15] have defined the practical charge density of the doping anions $\left(\rho_{c}\right)$, as $\rho_{c}=q / N_{p}$, where $\rho_{c}=$ practical charge density, $q=$ charge, and $N_{p}=$ practical number of atoms among which the charge is formally dissipated. In this sense, $\rho_{\mathrm{c}}\left(\mathrm{Cl}^{-}\right)=1 / 1$, $\rho_{\mathrm{c}}\left(\left[\mathrm{NO}_{3}\right]^{-}\right)=1 / 3, \rho_{\mathrm{c}}\left(\left[\mathrm{SO}_{4}\right]^{2-}\right)=2 / 4, \rho_{\mathrm{c}}\left(\left[\mathrm{R}_{-}-\mathrm{SO}_{3}\right]^{-}\right)=1 / 3, \rho_{\mathrm{c}}\left(\left[\mathrm{C}_{60}\right]^{-}\right)=1 / 60, \rho_{\mathrm{c}}\left(\left[\mathrm{CB}_{9} \mathrm{H}_{10}\right]^{-}\right)=1 / 20$, $\rho_{\mathrm{c}}\left(\left[\mathrm{Co}\left(\mathrm{C}_{2} \mathrm{~B}_{9} \mathrm{H}_{11}\right)_{2}\right]^{-}\right)=1 / 45, \rho_{\mathrm{c}}\left(\left[\mathrm{B}_{10} \mathrm{Cl}_{10}\right]^{2-}\right)=2 / 20$. Although $\rho_{\mathrm{c}}$ may not have a real physical meaning, it provides a convenient value at the time of choosing a possible doping agent. Then, if a small $\rho_{\mathrm{c}}$ is sought, $\left[\mathrm{Co}\left(\mathrm{C}_{2} \mathrm{~B}_{9} \mathrm{H}_{11}\right)_{2}\right]^{-}$, would be superior than $\left[\mathrm{CB}_{9} \mathrm{H}_{10}\right]^{-}$, and $\left[\mathrm{B}_{10} \mathrm{Cl}_{10}\right]^{2-}$ in improving the overoxidation resistance of the material. The cobaltabisdicarbollide anion, $\left[\mathrm{Co}\left(\mathrm{C}_{2} \mathrm{~B}_{9} \mathrm{H}_{11}\right)_{2}\right]^{-}$, whose molecular structure is depicted in Fig. 1, consists of a $\mathrm{Co}$ (III) ion sandwiched by two dicarbollide moieties. Each dicarbollide unit $\left[\mathrm{C}_{2} \mathrm{~B}_{9} \mathrm{H}_{11}\right]^{2-}$ bears two negative charges, overall producing a mononegative species. This cobaltabisdicarbollide anion presents a great chemical resistance [5], e.g., it withstand in $\mathrm{HNO}_{3} 2 \mathrm{M}$ and in concentrated $\mathrm{HCl}$ for several days without apparent decomposition [16-18]. Potentiodynamic overoxidation measurements [19] on several polypyrrole membranes $\mathrm{PPy}[\mathrm{X}](\mathrm{X}=$ common doping agent or cluster anionic agent) have been performed, and their overoxidation resistance expressed in volts with reference to $\mathrm{Ag} / \mathrm{AgCl} / \mathrm{Cl}^{-}(0.1 \mathrm{M}$ acetonitrile) indicated in parenthesis $\mathrm{PPy}\left[\mathrm{ClO}_{4}\right]$ (0.91); $\mathrm{PPy}\left[\mathrm{B}_{10} \mathrm{Cl}_{10}\right]$ (0.89); $\mathrm{PPy}\left[\mathrm{CB}_{11} \mathrm{H}_{12}\right]$ (1.09); $\mathrm{PPy}\left[\mathrm{Co}\left(\mathrm{C}_{2} \mathrm{~B}_{9} \mathrm{H}_{8} \mathrm{Br}_{3}\right)_{2}\right]$ (1.11); $\mathrm{PPy}\left[\mathrm{Co}\left(\mathrm{C}_{2} \mathrm{~B}_{9} \mathrm{H}_{8} \mathrm{Cl}_{3}\right)_{2}\right]$ (1.18); $\mathrm{PPy}\left[\mathrm{Co}\left(\mathrm{C}_{2} \mathrm{~B}_{9} \mathrm{H}_{11}\right)_{2}\right]$ (1.25). The higher the potential the more resistant the material to overoxidation. The gap between the set of common anions and this of the low nucleophilic species is of $300 \mathrm{mV}$ approximately. The high overoxidation potential is presumably due to the high hydrophobicity of $\left[\mathrm{Co}\left(\mathrm{C}_{2} \mathrm{~B}_{9} \mathrm{H}_{11}\right)_{2}\right]^{-}$[20] that shields the polymer from the nucleophilic attack by $\mathrm{OH}^{-}$[21]. These differentiating results suggest that they must be due, in great part, to the nonnucleophilic anion in the polymer. We observe, then, that not all clusters produce a high overoxidation resistance, and that the dianionic cluster $\left[\mathrm{B}_{10} \mathrm{Cl}_{10}\right]^{2-}$ produces $\mathrm{PPy}\left[\mathrm{B}_{10} \mathrm{Cl}_{10}\right]$ with an overoxidation resistance similar to those measured for materials doped with common anions. We have presented this example to show one particular case where the cluster nature of the anion, the delocalization of its charge and their "three-dimensional aromaticity" can make these borane anions very relevant. The $\mathrm{C}_{60}{ }^{-}$ or similar anions could do a similar task according to their $\rho_{c}$, however, their large spherical nature could prevent an adequate packing of the polymer threads.

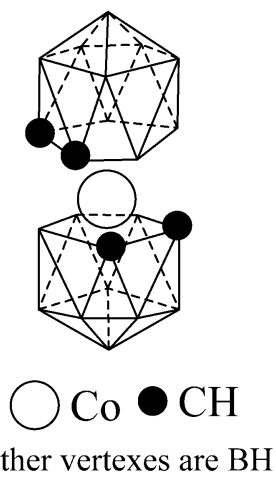

Fig. 1 


\section{METALLACARBORANES AS KHARASCH REACTION CATALYSTS}

In 1945, the seminal paper reported on the direct addition of carbon tetrachloride to olefinic double bonds (eq. 1). This process was catalyzed by peroxides as radical initiators [22].

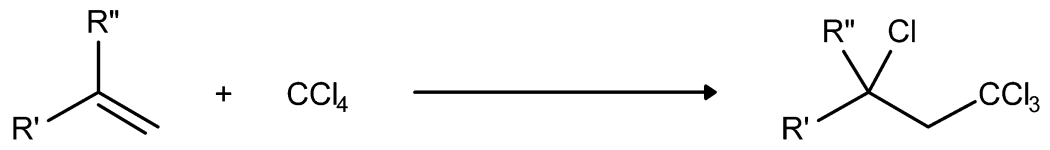

This simple reaction is a classic example of anti-Markovnikov addition and is known as the Kharasch addition reaction, in honor of its discoverer, M. S. Kharasch. A free-radical mechanism was presented to explain this kind of addition reaction, and it is now generally accepted to occur in this manner. The widespread use of the original free-radical addition is, however, limited because of competing telomerization and polymerization reactions.

By the mid-1950s, several groups began to investigate the use of transition metals and other compounds to promote this addition reaction. A number of species were found to initiate free-radical addition of polyhalogenated alkanes to alkenes. Telomerization and polymerization were still a recurring problem, however. Minisci was among the first to observe that $\mathrm{CCl}_{4}$ could be added to olefins to yield only the 1:1 adduct [23]. Research has clearly shown that a variety of polyhalogenated compounds can be added across a $\mathrm{C}=\mathrm{C}$ bond, and that virtually any olefin can serve as the source of reactive unsaturation. The list of promoters is now quite extensive and includes transition-metal complexes [24]. In contrast to AIBN [ $\alpha, \alpha^{\prime}$-azo-bis-(isobutyronitrile)]- or peroxide-promoted addition of halocarbons to alkenes, transition-metal complexes have demonstrated higher chemo- and regioselectivity for similar transformations. Ruthenium, in particular, has played a prominent role in Kharasch chemistry with $\left[\mathrm{RuCl}_{2}\left(\mathrm{PPh}_{3}\right)_{3}\right]$ displaying some of the highest efficiency and versatility for halocarbon activation and addition to alkenes [25]. Despite its interest in organic synthesis, $\left[\mathrm{RuCl}_{2}\left(\mathrm{PPh}_{3}\right)_{3}\right]$ suffers from two severe limitations. (i) A relatively high amount of catalyst is needed, around $1-15 \mathrm{~mol} \%$ depending on the halocarbon and the olefin used. (ii) Rather harsh reaction conditions are often used with temperatures ranging from $80{ }^{\circ} \mathrm{C}$ (with $\mathrm{CCl}_{4}$ as the halocompound) to $140{ }^{\circ} \mathrm{C}$ with chloroform [26]. In search of more active ruthenium-based systems, we have recently reported on the use of Grubbs' rutheniumbenzylidene complexes, $\left[\mathrm{RuCl}_{2}(=\mathrm{CHPh})\left(\mathrm{PR}_{3}\right)_{2}\right]$ [27] and $\left[\mathrm{RuCl}\left(\mathrm{Cp}^{\#}\right)\left(\mathrm{PAr}_{3}\right)_{2}\right]\left(\mathrm{Cp}^{\#}=\mathrm{Cp}, \mathrm{Cp}^{*}\right.$, and indenyl) [28] as efficient catalysts for Kharasch reactions.

Since formation of unsaturated 14-electron ruthenium species through phosphine dissociation from $\left[\mathrm{RuCl}_{2}\left(\mathrm{PPh}_{3}\right)_{3}\right]$ is assumed to take place prior to halocarbon activation [28,29], we anticipated that stable, well-defined 14-electron complexes should give a direct access to the catalytic species. With this in mind, we investigated in Kharasch chemistry the catalytic activity of unsaturated 14-electron ruthenium complexes $\left[\mathrm{Ru}\left(7,8-\left(\mathrm{PPh}_{2}\right)-7,8-\right.\right.$ nido- $\left.\left.\mathrm{C}_{2} \mathrm{~B}_{9} \mathrm{H}_{10}\right) \mathrm{X}\left(\mathrm{PPh}_{3}\right)_{2}\right]$ (2) with anionic carborane phosphine

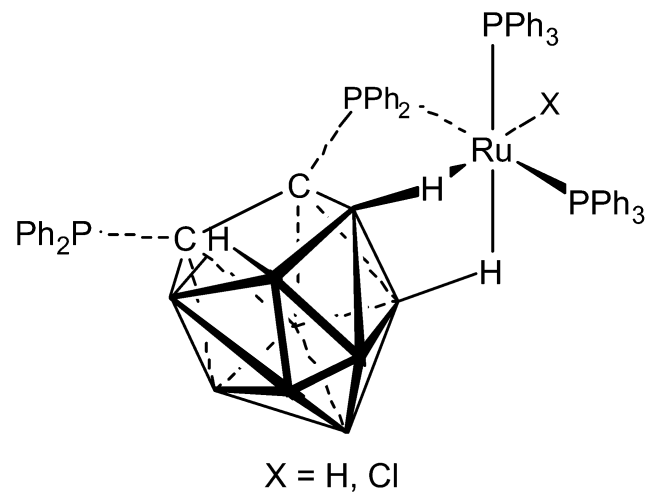

Fig. 2 
ligands, in which the empty coordination sites at the metal are stabilized by two B-H $\rightarrow$ Ru agostic interactions (see Fig. 2).

For addition of carbon tetrachloride to model substrates such as $n$-butyl acrylate, methyl methacrylate, styrene, and 1-decene, complexes 2 showed a reactivity profile similar to that of $\left[\mathrm{RuCl}_{2}\left(\mathrm{PPh}_{3}\right)_{3}\right](3)[30]$.

Recent research has also demonstrated that $\left[\mathrm{RuCl}\left(\mathrm{Cp}^{*}\right)\left(\mathrm{PPh}_{3}\right)_{2}\right](\mathbf{4})$ and $\left[\mathrm{RuCl}(\mathrm{Ind})\left(\mathrm{PPh}_{3}\right)_{2}\right](\mathbf{5})$ were excellent catalyst precursors for promoting the Kharasch addition of $\mathrm{CCl}_{4}$ and $\mathrm{CHCl}_{3}$ across olefins under mild reaction conditions (at temperatures as low as $40{ }^{\circ} \mathrm{C}$ with $\mathrm{CCl}_{4}$ ) [28]. The effect of the substituents on the cyclopentadienyl ring has been investigated. $\left[\mathrm{RuCl}(\mathrm{Cp} *)\left(\mathrm{PPh}_{3}\right)_{2}\right]$ and $\left[\mathrm{RuCl}(\mathrm{Ind})\left(\mathrm{PPh}_{3}\right)_{2}\right]$ surpass in terms of efficiency and activity the best ruthenium systems reported so far. As with $\left[\mathrm{RuCl}_{2}\left(\mathrm{PPh}_{3}\right)_{3}\right]$, a two-step mechanism has been suggested, in which the extrusion of a phosphine ligand occurs prior to the activation of the halogenated compound by the unsaturated ruthenium center. Since Kharasch addition relies on the capacity of the metal complex to undergo a pseudooxidative one-electron addition of the carbon-halogen bond of the polyhalogenated compound, formally yielding a ruthenium(III) species, we reasoned that the catalyst might be fine-tuned through modification of the $\mathrm{Cp \#}$ ligand.

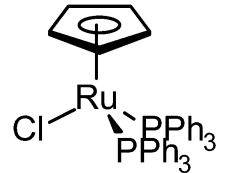

3

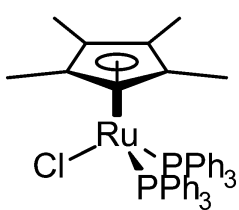

4

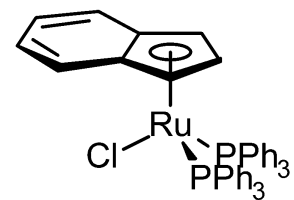

5

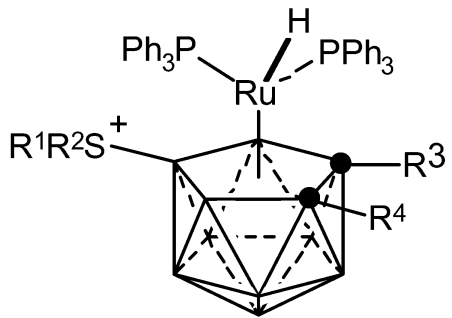

6

With this in mind and with the interest of developing new synthetic opportunities for metallacarboranes, ruthenium complexes $(\mathbf{6})$ were prepared in which the uninegative carborane anion was obtained by introducing sulfonium substituents to the parent anion $\left[\mathrm{C}_{2} \mathrm{~B}_{9} \mathrm{H}_{11}\right]^{2-}$. Gratifyingly, complexes (6) proved to highly outperform their isolobal $\mathrm{Cp}^{\#}$ analogs (3-4) in Kharasch chemistry, both in turnover frequencies (TOFs) and total turnover numbers (TONs). TON of 4300 and 9000, and initial TOF of 800 and $1500 \mathrm{~h}^{-1}$ were obtained at $40{ }^{\circ} \mathrm{C}$ with methyl methacrylate and styrene, respectively, as opposed to maximum TON of 1700 and TOF of $400 \mathrm{~h}^{-1}$ observed with $\left[\mathrm{RuCl}(\mathrm{Cp} *)\left(\mathrm{PPh}_{3}\right)_{2}\right]$ (4). In addition, the TONs were even higher than with the diaminoarylnickel(II) "pincer" complexes, to this point the most efficient catalysts ever reported for Kharasch addition [31].

\section{O-CARBORANYL AS A UNIQUE ORGANIC GROUP}

The $o$-carborane, 1,2- $\mathrm{C}_{2} \mathrm{~B}_{10} \mathrm{H}_{12}$, is an icosahedral cluster with the two carbon atoms in adjacent positions. One way to build the orbital set of $o$-carborane is to consider that each participating atom has its valence orbitals set as two $\boldsymbol{s p}$, and two $\boldsymbol{p}$ orbitals. This situation is very similar to the molecular orbital requirements in acetylene. As a consequence, the $\mathrm{C}-\mathrm{H}$ of $o$-carborane is acidic and may be removed by strong bases. More on it, the closo-o-carborane cage through substitution on carbon is extremely electron-withdrawing. This characteristic and the fact that $o$-carborane has a rotating volume similar to the phenyl group should make this fragment attractive in organic chemistry reactions. The electron-withdrawing capacity of the C-o-carboranyl group and its singularity has been tested in producing the uncommon halogenophosphane molecular charge-transfer "spoke" structure. Although compounds of stoichiometry $\mathrm{R}_{3} \mathrm{PX}_{2}(\mathrm{R}=$ organic substituent, $\mathrm{X}=$ halogen $)$ have been known for over 100 years, their solid-state structure remains largely unexplored. Three basic structural motifs are found in the solid- 
state structures of $\mathrm{R}_{3} \mathrm{PX}_{2}$ : the trigonal bipyramidal found in $\mathrm{Ph}_{3} \mathrm{PF}_{2}[32],\left(\mathrm{C}_{6} \mathrm{~F}_{5}\right)_{3} \mathrm{PCl}_{2}, \mathrm{Ph}_{2}\left(\mathrm{C}_{6} \mathrm{~F}_{5}\right) \mathrm{PCl}_{2}$ [33], and $\mathrm{Ph}_{3} \mathrm{PCl}_{2}$ [34]; the molecular charge-transfer "spoke" structure for $t \mathrm{Bu}_{3} \mathrm{PI}_{2}$ [35]; and the ionic form, e.g., in $\left[n \mathrm{Pr}_{3} \mathrm{PCl}\right] \mathrm{Cl}[33]$ and $\left[\mathrm{Ph}_{3} \mathrm{PCl}\right] \mathrm{Cl}$ [36]. The existence of significant iodine-iodine interaction [35] in $t \mathrm{Bu}_{3} \mathrm{PI}_{2}$ stimulated research in the area, since a novel four-coordinate molecular structure in phosphane chemisty was found [37]. However, the I-I distance in $t \mathrm{Bu}_{3} \mathrm{PI}_{2}$ [3.326(1) $\AA$ ] was longer than in $\mathrm{Ph}_{3} \mathrm{AsI}_{2}$ [d (I-I)= 3.005(1) $\AA$ ] [38], the first reported molecular charge-transfer "spoke" structure. Other examples have also been reported, the observed I-I distances with the P-I distances are in parentheses are shown, $\mathrm{P}-\mathrm{I}$ are in brackets, $\mathrm{Ph}_{3} \mathrm{PI}_{2}$ (3.161(2) $\AA$ ) [2.481(4)] [37a], $\mathrm{PhMe}_{2} \mathrm{PI}_{2}$ (3.408(2)

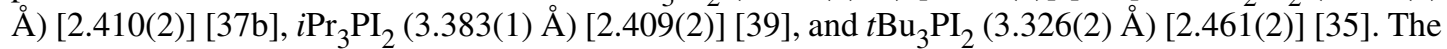
shortening of the I-I distance implies that elongation of P-I takes place. However, in no case the I-I distance has been found as short as in $\mathrm{Ph}_{3} \mathrm{AsI}_{2}$ [38]. For comparison, the I-I distance in $\mathrm{I}_{2}$ is $2.660 \AA$ [40]. The elongation of the I-I bond is expected since electron density is transferred into the $\sigma^{*}$ orbital of the diiodine by the electron donor. As a consequence the more basic are the phosphanes the longer will be the I-I distance and the shorter the P-I. Therefore, this was an adequate area in which to test the singularity of the $o$-carboranyl fragment.

There were several $o$-carboranylmonophosphines of the type (o-carboranyl) $\mathrm{R}_{2} \mathrm{P}$ available, but we decided to look for one of the highest basicity. For this occasion, we have chosen 1-PiPr $2-2-\mathrm{Me}-1,2-$ $\mathrm{C}_{2} \mathrm{~B}_{10} \mathrm{H}_{10}$. The decision to test a basic carboranylphosphine was to compensate for the $-\mathrm{I}$ (inductive effect) influence of the $o$-carboranyl cluster, on phosphorus. Again, the results have proven the uniqueness of the $o$-carboranyl fragment and (1-PiPr $\left.-2-\mathrm{Me}-1,2-\mathrm{C}_{2} \mathrm{~B}_{10} \mathrm{H}_{10}\right) \cdot \mathrm{I}_{2}$ was synthesized (see Fig. 3) and characterized providing the shortest I-I contact 3.021(1) $\AA$ and the corresponding longest P-I distance $2.5978(14) \AA$ [41] in a phosphane compound.

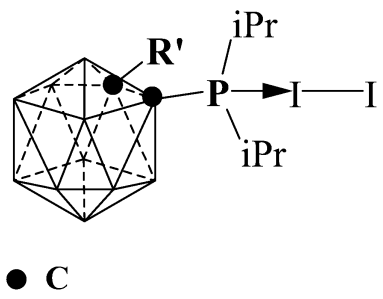

Other vertexes $\mathrm{BH}$

Fig. 3

\section{O-CARBORANE AS A FRAGMENT TO MODULATE C $\cdots$ C DISTANCES}

The $\mathrm{C} \cdots \mathrm{C}$ single, double, and triple bond distances are well defined in conventional organic compounds and distances of $1.54,1.34$, and $1.20 \AA$ are, respectively, considered standard. Some important exceptions exist, among them cationic norbornenyl derivatives, on which extensive theoretical studies have been conducted to evaluate the existence of nonclassical bonding. As an example, in [ $\left.\mathrm{Sm}\left(\mathrm{C}_{5} \mathrm{Me}_{5}\right)_{2}\left(\mathrm{O}_{2} \mathrm{C}_{7} \mathrm{Me}_{5}\right)\right]$, the $\mathrm{O}_{2} \mathrm{C}_{7} \mathrm{Me}_{5}$ adopts a norbornadiene structure [42], and a long C7-C2 of $1.876 \AA$ is found. This is much longer than two times the $\mathrm{C}$ single bond radii (1.54 $\AA$ ) [43]. Besides isolated cases, however, the possibility to tune up the $\mathrm{C}-\mathrm{C}$ distance in conventional organic compounds is rare. Cluster boron chemistry, in particular the $o$-carborane derivatives, provides the possibility to modulate the $\mathrm{C}-\mathrm{C}$ distance in an almost continuous way within the same family of compounds. $\mathrm{The}_{\mathrm{c}} \mathrm{C}_{\mathrm{c}} \cdots \mathrm{C}_{\mathrm{c}}$ distance in o-carborane is $1.64 \AA$, longer than the $\mathrm{C}-\mathrm{C}$ single bond. Examples of $\mathrm{C}_{\mathrm{c}} \cdots \mathrm{C}_{\mathrm{c}}$ elongation in metallacarboranes have been found with different metal ions [44-48]. Steric effects have been invoked to be responsible for $\mathrm{C}_{\mathrm{c}} \cdots \mathrm{C}_{\mathrm{c}}$ elongation [44a,49], but other data [45,50] suggest that electronic contributions may also be relevant. If Pauling's equation relating distance and bond order is applied we would encounter for the $o$-carborane cluster a bond order of 0.47 , already indicating that $o$-carborane itself has a nonconventional $\mathrm{C}-\mathrm{C}$ bond. Therefore $o$-carborane derivatives could provide a whole range of $\mathrm{C}-\mathrm{C}$ 
distances that would be of use, e.g., in chelating ligands. The $\mathrm{C}-\mathrm{C}$ distance of $1.876 \AA$ in the norbornadiene cation corresponds to a bond order of 0.33 . To modulate the bond order, hence the distance in $o$-carborane derivatives a combination of steric and electronic effects is adequate. The steric effects can be obtained modifying the volume of the substituents. This, however, does not modify largely the $\mathrm{C} \cdots \mathrm{C}$ distance. The major effects are obtained when elements with lone pairs are directly connected to the cluster carbon atoms. In this case, large $\mathrm{C} \cdots \mathrm{C}$ elongations are found. For instance, $1,2-\mathrm{C}_{2} \mathrm{~B}_{10} \mathrm{H}_{12}$ $1.629 \AA$ (1.624) [51], 1,2- $\mathrm{Et}_{2}-1,2-\mathrm{C}_{2} \mathrm{~B}_{10} \mathrm{H}_{10}(1.687 \AA), 1,2-\mathrm{Ph}_{2}-1,2-\mathrm{C}_{2} \mathrm{~B}_{10} \mathrm{H}_{10} \quad 1.733(4) / 1.720(4) * \AA$ $(1.764 \AA)$ [52], $1,2-(\mathrm{SH})_{2}-1,2-\mathrm{C}_{2} \mathrm{~B}_{10} \mathrm{H}_{10}(1.803 \AA), 1,2-(\mathrm{SPh})_{2}-1,2-\mathrm{C}_{2} \mathrm{~B}_{10} \mathrm{H}_{10} 1.798(3) \AA(1.818 \AA)$ [53], 1,2-(SMe) $)_{2}-1,2-\mathrm{C}_{2} \mathrm{~B}_{10} \mathrm{H}_{10} 1.803(2) \AA(1.836 \AA)$ [54], and 1,2- $\mu-\mathrm{SCH}_{2}\left(\mathrm{CH}_{2} \mathrm{OCH}_{2}\right)_{2} \mathrm{CH}_{2} \mathrm{~S}-1,2-$ $\mathrm{C}_{2} \mathrm{~B}_{10} \mathrm{H}_{10} 1.858(5) / 1.826(5) \AA^{*}(1.900 \AA)$ [55]. The B3LYP/6-31G computed $\mathrm{C}_{\mathrm{c}} \cdots \mathrm{C}_{\mathrm{c}}$ distances are given in parenthesis [53].

As it is shown there, binding of ethyl groups to $C_{c}$ does not change significantly the $C_{c} \cdots C_{c}$ distance. The presence of an electron-withdrawing and bulkier group, such as phenyl does increase this distance more, however, the most striking results, are the large $\mathrm{C}_{\mathrm{c}} \cdots \mathrm{C}_{\mathrm{c}}$ distances in thio- $\mathrm{C}_{\mathrm{c}}$-substituted $o$-carboranes.

Considering that $o$-carborane has a volume comparable to a rotating aromatic ring, it provides a convenient building block to construct new structures with more versatile $\mathrm{C} \cdots \mathrm{C}$ distances.

The lengthening caused by elements having lone pairs is interpreted by fragment orbital analysis considering partial filling of the cluster LUMO $\left(\Psi^{*}\right)$ orbital, mostly sited on the two carbon atoms, by the electron filled nonsymmetric orbital combination of the external sulfur atoms [53]. The new generated orbital has a non-negligible contribution of the former cluster LUMO, then producing an elongation of the C...C distance.

To summarize, and as it has been shown by the above results, the $\mathrm{C}_{\mathrm{c}} \cdots \mathrm{C}_{\mathrm{c}}$ distance in $\mathrm{C}_{\mathrm{c}}$-substituted $o$-carboranes can be modeled as function of the substituents. Purely alkyl substituents do not substantially alter the $\mathrm{C}_{\mathrm{c}} \cdots \mathrm{C}_{\mathrm{c}}$ distance of the parent compound, implying that steric effects, although relevant, are not the major cause of the lengthening. In contrast, substituents with lone pairs alter the $\mathrm{C}_{\mathrm{c}} \cdots \mathrm{C}_{\mathrm{c}}$ distance substantially. This cannot be explained by lone pair/lone pair repulsion or by the effect of electron-polarizing groups. The more plausible explanation is the transfer of electron density from the available lone pairs on the carbon substituents to the $\Psi^{*}$ orbitals, producing a decrease in the $\mathrm{C}_{\mathrm{c}} \cdots \mathrm{C}_{\mathrm{c}}$ bond order and, thereby, an increase in the $\mathrm{C}_{\mathrm{c}} \cdots \mathrm{C}_{\mathrm{c}}$ distance.

\section{REFERENCES}

1. (a) M. F. Hawthorne and A. Maderna. Chem. Rev. 99, 3421 (1999); (b) J. J. Schaeck and S. B Kahl. Inorg. Chem. 38, 204 (1999); (c) M. G. H. Vicente, D. J. Nurco, S. J. Shetty, C. J. Medforth, K. M. Smith. Chem. Commun. 483 (2001); (d ) A. H. Soloway, W. Tjarks, B. A. Barnum, F. G. Rong, R. F. Barth, I. M. Codogni, J. G. Wilson. Chem. Rev. 98, 1515 (1998).

2. (a) A. M. Thayer. Chem. Eng. News. 73, 15 (1995); (b) K. Shelly, C. A. Reed, Y. J. Lee, W. R. Scheidt. J. Am. Chem. Soc 108, 3117 (1986); (c) C. A. Reed. Acc. Chem. Res. 31, 325 (1998); (d) C. A. Reed, N. L. P. Fackler, K.-C. Kim, D. Stasko, D. R. Evans, P. D. W. Boyd, C. E. F. Rickard. J. Am. Chem. Soc. 121, 6314 (1999); (e) C. A. Reed. Acc. Chem. Res. 31, 133 (1998); (f) Z. Xie, R. Bau, C. A. Reed. Inorg. Chem. 34, 5403 (1995); (g) C. A. Reed and F. Guiset. J. Am. Chem. Soc. 118, 3281 (1996); (h) I. Zharov, B. T. King, Z. Havlas, A. Pardi, J. Michl. J. Am. Chem. Soc. 122, 10253 (2000); (i) D. Stasko and C. A. Reed. J. Am. Chem. Soc. 124, 1148 (2002); (j) M. J. Ingleson, M. F. Mahon, N. J. Patmore, G. D. Ruggiero, A. S. Weller. Angew. Chem., Int. Ed. 19, 3694 (2002).

\footnotetext{
${ }^{*}$ Two molecules in the asymmetric unit.
} 
3. (a) F. Teixidor, M. F. Flores, C. Viñas, R. Kivekäs, R. Sillanpää. Angew. Chem. 108, 2388 (1996); (b) F. Teixidor, M. F. Flores, C. Viñas, R. Sillanpää, R. Kivekäs. J. Am. Chem. Soc. 122, 1963 (2000); (c) P. E. Behnken, J. A. Belmont, D. C. Busby, M. S. Delaney, R. E. King III, C. W. Kreimendahl, T. B. Marder, J. J. Wilczynski, M. F. Hawthorne. J. Am. Chem. Soc. 106, 3011 (1984); (d) P. E. Behnken, D. C. Busby, M. S. Delaney, R. E. King III, C. W. Kreimendahl, T. B. Marder, J. J. Wilczynski, M. F. Hawthorne. J. Am. Chem. Soc. 106, 7444 (1984); (e) E. L. Hoel and M. F. Hawthorne. J. Am. Chem. Soc. 96, 4674 (1974); (f) J. A. Belmont, J. Soto, R. E. King III, A. J. Donaldson, J. D. Hewes, M. F. Hawthorne. J. Am. Chem. Soc. 111, 7475 (1989) and references therein; (g) H. C. Kang and M. F. Hawthorne. Organometallics 9, 2327 (1990); (g) V. N. Lebedev, E. V. Balagurova, F. M. Dolgushin, A. I. Yanovskii, L. I. Zakharkin. Russ. Chem. Bull 46, 550 (1997); (h) L. I. Zakharkin, D. D. Sulaimankulova, V. A. Lo'shevskaya. Zh. Obshch. Khim. 63, 188 (1993); (i) A. Demonceau, E. Saive, Y. de Froidmont, A. F. Noels, A. J. Hubert, I. Chizhevsky, I. A. Lobanova, V. I. Bregadze. Tetrahedron Lett. 33, 2009 (1992).

4. (a) J. Rais, M. Kyrs, J. Hermanek. Czech Patent 153 933, 1974; Chem. Abstr. 82 23370c (1975); (b) J. Rais, P. Selucký, M. Kyus. J. Inorg. Nucl. Chem. 38, 1376 (1976); (c) J. Plešek. Chem. Rev. 92, 269 (1992) and the references therein; (d) M. Kyrš, S. Heřmánek, J. Rais, J. Plešek. Czechoslovak Patent 182913 (11.2.1972); (e) P. Selucký, K. Baše, J. Plešek , S. Heřmánek, J. Rais, Czechoslovak Patent 215282 (1.8.1981); (f) J. Rais, P. Selucký, M. Kyrš. J. Inorg. Nucl. Chem. 38, 1742 (1976); (g) M. Štefek, M. Kyrš, J. Rais. Zh. Anal. Khim. 31, 1364 (1976); (h) L. N. Lazarev, R. I. Lyubtsev, B. Ya. Galkin, V. N. Romanovskii, D. N. Shishkin, M. Kyrs, P. Selucký, J. Rais, S. Heřmánek, J. Plešek. USSR Patent No. 1031088 (6.6.1981); (i) F. Teixidor, B. Čásenský, J. F. Dozol, S. Heřmánek, H. Mongeot, J. Rais. Final report, Contract New trends in the separation of $137 \mathrm{Cs}$ and $90 \mathrm{Sr}$ and transplutonium elements from radioactive $H L W$ by borane and heteroborane anions. Final report EC-INCO-Copernicus, Contract CIPA-CT 93-1333, European Comission, Nuclear Science and Technology 1998; (j) V. N. Romanovski. In Proceedings of the $5^{\text {th }}$ International Information Exchange Meeting on Actinide and Fission Product Partitioning and Transmutation, Mol, Belgium, 25-27 Nov. 77 (1998).

5. (a) C. Viñas, S. Gomez, J. Bertran, F. Teixidor, J.-F. Dozol, H. Rouquette. Chem. Commun. 191 (1998); (b) C. Viñas, S. Gomez, J. Bertran, F. Teixidor, J.-F. Dozol, H. Rouquette. Inorg. Chem. 37, 3640 (1998); (c) C. Viñas, J. Bertran, S. Gomez, F. Teixidor, J.-F. Dozol, H. Rouquette, R. Kivekäs, R. Sillanpää. J. Chem. Soc., Dalton Trans. 2849 (1998); (d) C. Viñas, S. Gomez, J. Bertran, J. Barron, F. Teixidor, J.-F. Dozol, H. Rouquette, R. Kivekäs, R. Sillanpää. J. Organomet. Chem. 581, 188 (1999); (e) B. Grüner, J. Plešek, J. Báča, I. Císařová, J.-F. Dozol, H. Rouquette, C. Viñas, P. Selucký, J. Rais. New J. Chem. 26, 1517 (2002).

6. (a) J. W. Gardner and P. N. Bartlett. Sens. Actuators A 51, 57 (1995); (b) R. H. Baughman. Synth. Met. 78, 33339 (1996); (c) G. Horowitz. Adv. Mater. 10, 365 (1998).

7. V. Savvateev, A. Yakimov, D. Davidov. Adv. Mater. 11, 519 (1999).

8. P. E. Burrows, V. Bulovic, S. R. Forrest, L. S. Sapochak, D. M. McCarty, M. E. Thompson. Appl. Phys. Lett. 65, 2922 (1994).

9. J. McElvain, H. Antoniadis, M. R. Hueschen, J. N. Miller, D. M. Roitman, J. R. Sheats, R. L. Moon. J. Appl. Phys. 80, 6002 (1996).

10. B. H. Cumpston, I. D. Parker, K. F. Jensen. J. Appl. Phys. 81, 3716 (1997).

11. Y. Li, J. Yang, J. Ouyang. Synth. Met. 74, 49 (1995).

12. Y. Y. Lee, D. Y. Kim, C. Y. Kim. Synth. Met. 74, 103 (1995).

13. J. Tamm, A. Alumaa, A. Hallik, V. Sammelselg. J. Electroanal. Chem. 448, 25 (1998).

14. (a) C. Masalles, S. Borros, C. Viñas, F. Teixidor. Adv. Mat. 12, 1199 (2000); (b) C. Masalles, S. Borrós, C. Viñas, F. Teixidor. Anal. Bioanal. Chem. 372, 513 (2002); (c) C. Masalles, S. Borrós, C. Viñas, F. Teixidor. Adv. Mater. 14, 449, (2002).

15. C. Masalles, J. Llop, F. Teixidor, C. Viñas. Adv. Mater. 14, 826 (2002).

16. E. Makrlik and P. Vaňura. Talanta 32, 423 (1985). 
17. J. Reis and P. Selucký. Nucleon. 1, 17 (1992).

18. I. B. Sivaer and V. I. Bregadze. Collect. Czech. Commun. 64, 783 (1999).

19. Potentiodynamic overoxidation resistance was measured by recording the current flow associated to this process during a single voltammetry scan (from 0 to $2 \mathrm{~V}$ ) in a $0.1 \mathrm{M} \mathrm{NaCl}$ solution at low scan rate $(0.5 \mathrm{mV} / \mathrm{s})$. The overoxidation process initially produces a current rising, and as the overoxidation proceeds the resistance of the sample increases leading to a current peak. The peak position allows us to get comparative results of overoxidation resistance of PPy samples synthesized under the same conditions.

20. J. Plesek. Chem. Rev. 92, 269 (1992).

21. J. R. Holze. J. Electroanal. Chem. 339, 411 (1992).

22. (a) M. S. Kharasch, E. V. Jensen, W. H. Urry. Science 102, 128 (1945); (b) M. S. Kharasch, E. V. Jensen, W. H. Urry. J. Am. Chem. Soc. 67, 1626 (1945).

23. F. Minisci. Acc. Chem. Res. 8, 165 (1975).

24. R. A. Gossage, L. A. van de Kuil, G. van Koten. Acc. Chem. Res. 31, 423 (1998).

25. H. Matsumoto, T. Nakano, Y. Nagai. Tetrahedron Lett. 14, 5147 (1973).

26. F. Simal, A. Demonceau, A. F. Noels. Recent Research Developments in Organic Chemistry, S. G. Pandalai (Ed.), Vol. 3, p. 455, Transworld Research Network, Trivandrum (1999).

27. (a) J. A. Tallarico, L. M. Malnick, M. L. Snapper. J. Org. Chem. 64, 344 (1999); (b) F. Simal, A. Demonceau, A. F. Noels. Tetrahedron Lett. 40, 5689 (1999).

28. (a) F. Simal, L. Wlodarczak, A. Demonceau, A. F. Noels. Tetrahedron Lett. 41, 6071 (2000); (b) F. Simal, L. Wlodarczak, A. Demonceau, A. F. Noels. Eur. J. Org. Chem. 2689 (2001).

29. (a) W. J. Bland, R. Davis, J. L. A. Durrant. J. Organomet. Chem. 267, C45-C48 (1984); (b) W. J. Bland, R. Davis, J. L. A. Durrant. J. Organomet. Chem. 280, 397 (1985).

30. F. Simal, S. Sebille, A. Demonceau, A. F. Noels, R. Núñez, M. Abad, F. Teixidor, C. Viñas. Tetrahedron Lett. 41, 5347 (2000).

31. O. Tutusaus, S. Delfosse, A. Demonceau, A. F. Noels, R. Núñez, C. Viñas, F. Teixidor. Tetrahedron Lett. 43, 983 (2002).

32. F. Weller, D. Nuszhar, K. Dehncke, F. Gingl, J. Strahle. Z. Anorg. All. Chem. 602, 7 (1991).

33. S. M. Godfrey, C. A. McAuliffe, R. G. Pritchard, J. M. Sheffield, G. M. Thompson. J. Chem. Soc., Dalton Trans. 4823 (1997).

34. S. M. Godfrey, C. A. McAuliffe, R. G. Pritchard, J. M. Sheffield. Chem. Commun. 921 (1998).

35. W.-W. du Mont, M. Bätcher, S. Pohl, W. Saak. Angew. Chem., Int. Ed. Engl. 26, 912 (1987); Angew. Chem. 99, 945 (1987).

36. M. A. HA Al-Juboori, P. N. Gates, A. S. Muir. J. Chem. Soc., Chem. Commun. 1270 (1991).

37. (a) S. M. Godfrey, D. G. Kelly, A. G. Mackie, C. A. McAuliffe, R. G. Pritchard, S. M. Watson. J. Chem. Soc., Chem. Commun. 1163 (1991); (b) N. Bricklebank, S. M. Godfrey, H. P. Lane, C. A. McAuliffe, R. G. Pritchard, M. M. Moreno. J. Chem. Soc., Dalton Trans. 2421 (1995).

38. C. A. McAuliffe, B. Beagley, G. A. Gott, A. G. Mackie, P. P. MacRory, G. Pritchard. Angew. Chem., Int. Ed. Engl. 26, 264-265 (1987); Angew. Chem. 99, 237 (1987).

39. F. Ruthe, P. G. Jones, W.-W. du Mont, P. Deplano, M. L. Mercuri. Z. Anorg. Allg. Chem. 626, 1105 (2000).

40. I. L. Karle. J. Chem. Phys. 23, 1739 (1955).

41. F. Teixidor, R. Núñez, C. Viñas, R. Sillanpää, R. Kivekäs. Angew. Chem., Int. Ed. 39, 4290 (2000); Angew. Chem. 112, 4460 (2000).

42. W. J. Evans, K. J. Forrestal, J. W. Ziller. J. Am. Chem. Soc. 117, 12635 (1995), and refs. therein.

43. N. W. Alcock. Bonding and Structure, Ellis Horwood (1990).

44. (a) Z. G. Lewis, A. J. Welch. J. Organomet. Chem. 430, C45 (1992); (b) U. Grädler, A. S. Weller, A. J. Welch, D. Reed. J. Chem. Soc., Dalton Trans. 335 (1996); (c) F. Teixidor, C. Viñas, M. A. Flores, G. M. Rosair, A. J. Welch, A. S. Weller. Inorg. Chem. 37, 5394 (1998). 
45. A. J. Welch. Steric Effects in Metallacarboranes in Metal Clusters in Chemistry, P. Braunstein, L. A. Oro, P. R. Raithby (Eds.), p. 69, Wiley-VCH, New York (1999).

46. F. Teixidor, M. A. Flores, C. Viñas, R. Sillanpää, R. Kivekäs. J. Am. Chem. Soc. 122, 1963 (2000).

47. J.-H. Kim, M. Lamrani, J-W. Hwang, Y. Do. Chem. Commun. 1761 (1997).

48. J. Llop, C. Viñas, F. Teixidor, L. Victori, R. Kivekäs, R. Sillanpää. Organometallics 19, 4024 (2001).

49. U. Grädler, A. S. Weller, A. J. Welch, D. Reed. J. Chem. Soc., Dalton Trans. 335 (1996).

50. R. Kivekäs, R. Sillanpää, F. Teixidor, C. Viñas, R. Nuñez, M. Abad. Acta Cryst. C51, 1864 (1995)

51. M. G. Davidson, T. G. Hibbert, J. A. K. Howard, A. Mackinnon, K. Wade. Chem. Commun. 2285 (1996).

52. Z. G. Lewis and A. J. Welch. Acta Cryst. C49, 705 (1993).

53. J. Llop, C. Viñas, J. M. Oliva, F. Teixidor, M. A. Flores, R. Kivekäs, R. Sillanpää. J. Organomet. Chem. 657, 232 (2002).

54. A. Laromaine, J. Llop, F. Teixidor, C. Viñas, R. Sillanpää, R. Kivekäs. Unpublished results.

55. F. Teixidor, C. Viñas, J. Rius, C. Miravitlles, J. Casabó. Inorg. Chem. 29, 149 (1990). 